\title{
The inheritance of mitochondrial DNA in cattle
}

A. J. van Reeuwijk, S. Korver and J. H. J. van der Werf (Dept. of Animal Breeding, Wageningen Agricultural University, P.O. Box 338, NL 6700 AH Wageningen, Netherlands)

Received 9 December 1987; accepted 9 March 1988

Abstract. Important processes, such as oxidative phosphorylation and mitochondrial protein syntheses, are influenced by mitochondrial (mt) DNA, which is partly independent from nuclear DNA. Researchers have described a rapid nucleotide variation of mtDNA over twenty years between maternally related individuals. In general, the knowledge of the inheritance of mtDNA is limited. A number of studies have focussed on quantifying the cytoplasmic effect on production and reproduction traits in cattle. These studies show significant cytoplasmatic effects on milk production traits and effects on reproduction that were nearly significant.

Key words: cytoplasmic inheritance, mitochondrial DNA

Introduction. A number of studies suggest that cytoplasmic inheritance may influence milk production traits of dairy cattle. A potential approach to explain these cytoplasmic effects is to study mitochondrial deoxyribonucleic acid (mtDNA), which carries the genetic information essential to mitochondrial function (Hutchison et al., 1977). In contrast to the chromosomal genome, which is inherited from both sire and dam, Hutchison et al. (1977) found that the mitochondrial genome is inherited solely from the dam. Cytoplasmic inheritance, in addition to nuclear inheritance, could be important in selecting cows to produce embryos for transfer and splitting. This synopsis reports on the literature on physiological aspects of the inheritance of mtDNA in cattle and the methods used to quantify the effect.

Physiological aspects of the inheritance of mitochondrial DNA. Dzapo \& Wassmuth (1983) found that nearly $85-90 \%$ of the required proteins for the biogenesis of mitochondria are nuclear (n) DNA coded. The enzymes that are specific to the mtDNA transcription and replication processes are probably also nDNA coded (Anderson et al., 1981). However, the control of replication and transcription of mtDNA is autonomous, according to Alberts et al. (1983). This implies that nDNA has an important impact on the biogenesis of mitochondria and replication of mtDNA. An important question is how much does mtDNA affect important processes like oxidative phosphorylation and mitochondrial protein synthesis independently of nDNA.

Many studies demonstrate heterogeneity in mtDNA within the species and homogeneity within one single animal (reviewed by Bell et al., 1985). However, Hauswirth \& Laipis (1982), Laipis et al. (1982) and Olivo et al. (1983) describe a rapid change in nucleotides over twenty years between maternally related individuals. Mutation alone does not sufficiently account for this variation. Other factors, 


\section{A. J. VAN REEUWIJK, S. KORVER AND J. H. J. VAN DER WERF}

such as the existence of mtDNA sequence heterogeneity within the female germ line, have been postulated (Olivo et al., 1983) as a cause. Hauswirth et al. (1984) have documented the existence of a heterogeneous population of mitochondrial genotypes within the tissues of individual dairy cows. They suggest that such heterogeneous tissues reflect a state of intracellular mtDNA heterogeneity (heteroplasmy).

Current detection methods indicate that inheritance of mtDNA is strictly maternal in mammals. The average number of paternal mtDNA contributed to the next generation is estimated to be no more than one per thousand maternal mtDNA contributed (Gyllensten et al., 1985). However, if paternal mtDNA survives and mtDNA molecules replicate and segregate at random (Birky, 1983), a rapid mitochondrial nucleotide shift could occur within a maternal line.

Quantifying the cytoplasmic effects. Bell et al. (1985) and Huizinga et al. (1986) used a quantitative approach to determine the importance of maternal lines within the Black and White dairy cattle population. Variation in mtDNA between lines and the impact of mitochondria on milk production traits make it reasonable to assume that extra-nuclear genetic variation in mitochondria may be responsible for some of the variation in milk production traits of dairy cattle. Evidence (reviewed by Bell et al., 1985; Huizinga et al., 1986) for this includes:

- Higher heritability estimates $\left(h^{2}\right)$ from daughter-dam regression compared to those from paternal half sib correlations.

- The importance of a cow's performance in predicting the merit of her daughter is higher than expected and it is lower than expected for predicting her son's progeny test results.

- Significant differences in production traits between reciprocal crosses in crossbreeding studies with dairy breeds.

Differences in cytoplasmic lines in the data of Huizinga et al. (1986) were larger than in the study of Bell et al. (1985). Cytoplasmic origin was a significant $(P<$ 0.01 ) source of variation in fat plus protein yield and milk returns (expressed in Dutch guilders). They account for $10 \%$ and $13 \%$ of the variation, respectively. In both studies, cytoplasmic effects on reproduction were either significant or nearly significant.

An alternative interpretation of the results of Bell et al. (1985) is given by Kennedy (1987). He simulated the design of Bell et al. (1985) with no cytoplasmic effects. Analysis of the simulated data produced estimates of variance due to cytoplasmic origin that were comparable to those of Bell et al. (1985). Kennedy (1987) concludes that the observed results probably reflected residual additive genetic effects representing drift variance, which was unaccounted for by the models used. Reed \& van Vleck (1987) estimated heritabilities from daughter-dam and daughter-granddam regression. Analysis of residuals showed that cytoplasmic effects did not account for variation in milk and fat yield or fat percent. Kennedy (1987) proposed a complete animal model that includes all additive genetic effects.

Conclusion. Increased use of embryo transfer techniques in cattle makes it desira- 
ble to determine the importance of cytoplasmic inheritance. However the mechanism of mtDNA inheritance, the frequency of (intracellular) sequence variation between and within maternally related individuals and the amount of autonomy of mtDNA in respect of nDNA are only partly understood in mammals. This limited knowledge restricts the value of the analytical approaches used by Bell et al. (1985) and Huizinga et al. (1986) to determine the extent of cytoplasmic effects. Interdisciplinary studies between biochemistry, molecular genetics and quantitative population genetics are necessary for a better understanding of the nuclear and mitochondrial DNA effect.

\section{References}

Alberts, B., D. Bray \& J. Lewis, 1983. Molecular biology of the cell. Chapter 9. Garland Publishing Inc., New York/London.

Anderson, S., A. T. Bankier, B. G. Barell, M. H. L. de Bruijn, A. R. Coulson, J. Drouin, T. C. Eperen, D. F. Nierlich, B. A. Roe, F. Sanger, P. H. Schreider, A. J. H. Smits, R. Staden \& I. G. Young, 1981. Sequence and organization of the human mitochondrial genome. Nature 290: 457-465.

Bell, B. R., B. T. McDaniel \& O. W. Robison, 1985. Effects of cytoplasmic inheritance on production traits of dairy cattle. Journal of Dairy Science 68: 2038-2061.

Birky, C.W. Jr., 1983. Relaxed cellular controls and organelle heredity. Science 222: 468-475.

Dzapo, V. \& R. Wassmuth, 1983. Mitochondrialer Stoffwechsel und heterorische Effekten beim Schwein. Ergebnisse eines reziproken Kreuzungsversuches. II. Atmungsaktivität und oxydative Phosphorylierung in Herz-, Leber- und Hodenmitochondrien. Zeitschrift für Tierzüchtung und Züchtungsbiologie 100: 280-295.

Gyllensten, U., D. Wharton \& A. C. Wilson, 1985. Maternale inheritance of mitochondrial DNA during back crossing of two species of mice. Journal of Heredity 76: 321-324.

Hauswirth, W.W. \& P. J. Laipis, 1982. Mitochondrial DNA polymorphism in a maternal lineage of Holstein cows. Proceedings National Academy of Science, USA 79: 4686-4690.

Hauswirth, W. W., M. J. van der Walle, P. J. Laipis \& P. D. Olivo, 1984. Heterogeneous mitochondrial DNA D-loop sequences in bovine tissue. Cell 37: 1001-1007.

Huizinga, H. A., S. Korver, B. T. McDaniel \& R. D. Politiek, 1986. Maternal effects due to cytoplasmic inheritance in dairy cattle. Influence on milk production and reproduction traits. Livestock Production Science 15: 11-26.

Hutchison, C. A., J. E. Newbold, S. S. Potter \& M. H. Edgell, 1974. Maternal inheritance of mammalian mitochondrial DNA. Nature 251: 535-538.

Kennedy, B. W., 1986. A further look at evidence for cytoplasmic inheritance of production traits in dairy cattle. 81st Annual Meeting of the American Dairy Science Association 69:99.

Laipis, P. J., C. J. Wilcox \& W. W. Hauswirth, 1982. Nucleotide sequence variation in mitochondrial deoxyribonucleic acid from bovine liver. Journal of Dairy Science 65: 1655-1662.

Olivo, P. D., M. J. van der Walle, P. J. Laipis \& W. W. Hauswirth, 1983. Nucleotide sequence evidence for rapid genotypic shifts in the bovine mitochondrial DNA D-loop. Nature (London) 306: 400-402.

Reed, P. D. \& L. D. van Vleck, 1987. Lack of evidence of cytoplasmic inheritance in milk production traits of dairy cattle. Journal of Dairy Science 70: 837-841.

This synopsis is based on an undergraduate thesis 'Literatuurstudie naar: mitochondrieel DNA in zoogdiercellen' by A. van Reeuwijk, Department of Animal Breeding, Wageningen Agricultural University, Wageningen, 1988. 65 pp., 11 figs., 48 refs. Available as paper copy (order R082P, $f 10$ including postage) at: NARD, clo Pudoc, P.O. Box 4, 6700 AA Wageningen (telex 45015 blhwg). 